Louisiana State University

LSU Digital Commons

Faculty Publications

Department of Geology and Geophysics

$2-15-2020$

\title{
Human impact overwhelms long-term climate control of fire in the Yangtze River Basin since 3.0 ka BP
}

\author{
Wenqiang Pei \\ Institute of Oceanology Chinese Academy of Sciences \\ Shiming Wan \\ Institute of Oceanology Chinese Academy of Sciences \\ Peter D. Clift \\ Louisiana State University \\ Jiang Dong \\ Institute of Oceanology Chinese Academy of Sciences \\ Xiting Liu \\ Ocean University of China
}

See next page for additional authors

Follow this and additional works at: https://digitalcommons.Isu.edu/geo_pubs

\section{Recommended Citation}

Pei, W., Wan, S., Clift, P., Dong, J., Liu, X., Lu, J., Tan, Y., Shi, X., \& Li, A. (2020). Human impact overwhelms long-term climate control of fire in the Yangtze River Basin since 3.0 ka BP. Quaternary Science Reviews, 230 https://doi.org/10.1016/j.quascirev.2020.106165

This Article is brought to you for free and open access by the Department of Geology and Geophysics at LSU Digital Commons. It has been accepted for inclusion in Faculty Publications by an authorized administrator of LSU Digital Commons. For more information, please contact ir@lsu.edu. 
Authors

Wenqiang Pei, Shiming Wan, Peter D. Clift, Jiang Dong, Xiting Liu, Jian Lu, Yang Tan, Xuefa Shi, and Anchun Li 


\title{
Human impact overwhelms long-term climate control of fire in the Yangtze River Basin since 3.0 ka BP
}

\author{
Wenqiang Pei ${ }^{\text {a, }}$, Shiming Wan ${ }^{\text {a, b, d, * , Peter D. Clift }}{ }^{e}$, Jiang Dong a , Xiting Liu ${ }^{\mathrm{f}}$, Jian Lu ${ }^{\mathrm{a}}$, \\ Yang Tan ${ }^{\mathrm{g}}$, Xuefa Shi ${ }^{\mathrm{h}}$, Anchun $\mathrm{Li}^{\mathrm{a}}$ \\ a Key Laboratory of Marine Geology and Environment, Institute of Oceanology, Chinese Academy of Sciences, Qingdao, 266071, China \\ ${ }^{\mathrm{b}}$ Laboratory for Marine Geology, Qingdao National Laboratory for Marine Science and Technology, Qingdao, 266061, China \\ ${ }^{\mathrm{c}}$ University of Chinese Academy of Sciences, Beijing, 100049, China \\ ' CAS Center for Excellence in Quaternary Science and Global Change, Xi'an, 710061, China \\ e Department of Geology and Geophysics, Louisiana State University, Baton Rouge, LA, 70803, USA \\ ${ }^{\mathrm{f}}$ Key Laboratory of Submarine Geosciences and Prospecting Technology, College of Marine Geosciences, Ocean University of China, Qingdao, 266100, China \\ ${ }^{g}$ Yantai Institute of Coastal Zone Research, Chinese Academy of Sciences, Yantai, 264003, China \\ ${ }^{\mathrm{h}}$ Key Laboratory of Marine Sedimentology and Environmental Geology, First Institute of Oceanography, Ministry of Natural Resources, Qingdao, 266061, \\ China
}

\section{A R T I C L E I N F O}

\section{Article history:}

Received 17 October 2019

Received in revised form

1 January 2020

Accepted 2 January 2020

Available online 22 January 2020

\section{Keywords:}

Fire history

Black carbon

Yangtze river basin

East China sea

Holocene

Anthropocene

\begin{abstract}
A B S T R A C T
A high-resolution fire history in the Yangtze River Basin over the past 7.0 ka BP is reconstructed based on the proxy of black carbon of sediment core ECMZ on the continental shelf of the East China Sea in order to reveal the interactions among fire, climate, vegetation and human activity on a regional scale. A comparison of fire activity with climatic and vegetation proxies suggests that changes in fire activity prior to $3.0 \mathrm{ka} \mathrm{BP}$ on both millennial- and centennial-timescales were closely related to variations in temperature and precipitation, with more fire during warm and humid periods, suggesting climatic control on regional fire activities. In contrast, the significant decoupling between fire and climate on multi-timescales since $\sim 3.0$ ka BP implies increasing anthropogenic impact on regional fire activity. There is also a distinct response of fire activity to human disturbance at different time scales. Long-term reduction in regional fire activity since $\sim 3.0 \mathrm{ka} \mathrm{BP}$ was caused by a general decrease in forest cover with increasing human activity while short-term (centennial-timescale) enhancement in biomass burning usually coincides with periods characterized by increasing human activity associated with population migration or technological advances.
\end{abstract}

๑ 2020 Elsevier Ltd. All rights reserved.

\section{Introduction}

Fire has made significant impact on the global carbon cycle by regulating terrestrial ecosystems (Bond-Lamberty et al., 2007) and altering atmospheric composition (Justino et al., 2010). Previous studies revealed that the characteristics of fire are closely related with climate, vegetation and human activity (Li et al., 2009a; Wang et al., 2013). As a result, a better understanding of the interactions among these processes is required for assessing the sensitivity of fire to such controls (Daniau, 2012). In turn this can provide a knowledge base for predicting future fire activity (Marlon et al.,

\footnotetext{
* Corresponding author. Key Laboratory of Marine Geology and Environment, Institute of Oceanology, Chinese Academy of Sciences, Qingdao, 266071, China.

E-mail address: wanshiming@ms.qdio.ac.cn (S. Wan).
}

2009) and its related feedbacks on climate and ecosystems (Gf and Woodward, 2010). Such findings will assist in fire preparedness and fire management policy.

The links between fire, climate, vegetation and human disturbance can be illuminated by reconstructing paleofire history and comparing this with potential controlling factors (Marlon et al., 2009). Evidence from charcoal and black carbon records has shown that the response of fire to climate and vegetation varies with different spatial and temporal scales. For example, an increase in precipitation can lead to fewer fires by lessening fire-prone weather and increasing fuel moisture (Archibald et al., 2009; Xue et al., 2018), but can also cause more biomass burning with an abundant fuel load available under a humid climate (Han et al., 2012). Furthermore, the role of human activity in altering fire is still under debate. Local fire records near archaeological sites 
suggest that human-induced fire can date back to at least the middle Holocene (Wang et al., 2013; Zong et al., 2007), and thus prehistoric human-induced fire has significantly affected earth systems since long before the industrial revolution (Bird and Cali, 1998; Glikson, 2013). But whether and when the long-term changes in fire at broad spatial scales can be explained by human activity remains controversial (Marlon et al., 2013; Quintana Krupinski et al., 2013), largely due to the lack of a sediment record of regional fire reconstruction.

China, home to one of the earliest human civilizations, is ideal for assessing the broad-scale response of fire to combined impacts of natural factors and human activity. Recent studies of fire history in China, however, concentrated on northern China and emphasized local scales (Wang et al., 2013). In contrast, less attention has been paid to the regional fire history in southern and eastern China and its relationships with climate, vegetation and human activity.

The Yangtze River Basin covers an area of more than $1.8 \times 10^{6} \mathrm{~km}^{2}$, most of which lies in the subtropical zone of the China (Fig. 1). Under the influence of East Asian monsoon system, the mean annual temperature ranges from 14 to $22{ }^{\circ} \mathrm{C}$, and the mean annual precipitation is $1000-1500 \mathrm{~mm}$, with most precipitation occurring during the summer months (Chen et al., 2009). As one of the culture cradles of ancient China (Wu et al., 2012), the Yangtze River Basin is rich in archaeological sites. Complete Neolithic cultural sequences have been observed in the upper, middle and lower reaches of the Yangtze River (Wu et al., 2012). Moreover, this region was one in which rice domestication first started (Zheng and Jiang, 2009), which was an important step in the development of agriculture (Atahan et al., 2008; Zong et al., 2007).

Black carbon in marine sediments has the potential to reconstruct fire history at subcontinental to continental scales (Bird and Cali, 1998). The continental shelf of the East China Sea received huge volumes of sediment from the Yangtze River (Liu et al., 2007; Xu et al., 2012), and started to form the Zhejiang-Fujian Mud Belt
(ZFMB) on the inner shelf (Fig. 1) around 7.0 ka BP after sea level reached a highstand in the middle Holocene (Liu et al., 2006). This makes the ZFMB a good archive for reconstructing the fire history of the Yangtze River Basin. In this paper, we present a high-resolution black carbon record from core ECMZ (Fig. 1) taken from the continental shelf of the East China Sea in order to: (1) reconstruct fire history in the Yangtze River Basin since $7.0 \mathrm{ka}$ BP; and (2) explore fire-climate-vegetation-human relationships and thus to assess the relative importance of natural versus anthropogenic forcing on fire in southern China.

\section{Materials and methods}

\subsection{Core description and dating}

Core ECMZ $\left(28^{\circ} 30^{\prime} 00^{\prime \prime} \mathrm{N}, 122^{\circ} 10^{\prime} 00^{\prime \prime} \mathrm{E}\right)$ was drilled and recovered on the inner shelf of the East China Sea (Fig. 1) at a water depth of $40 \mathrm{~m}$ by the drilling vessel Kan 407 in September 2015. The upper $13 \mathrm{~m}$ of ECMZ was chosen for this study because the recovered sediments in this part are dominated by homogeneous dark gray clayey silt and silty clay, with occasionally intact shells, implying relatively stable shallow water sedimentary environments. An age model developed by Dong et al. (2018) suggests that the upper $13 \mathrm{~m}$ of ECMZ has been deposited since $\sim 7.0 \mathrm{ka}$ BP, corresponding to the time when sea level reached to a highstand and ZFMB began forming. To improve the quality of the age model, four additional AMS ${ }^{14} \mathrm{C}$ ages of benthic foraminifera for the upper $13 \mathrm{~m}$ of core ECMZ were measured. A new age model was established based on a total of eight AMS ${ }^{14} \mathrm{C}$ ages after being calibrated to calendar ages using the program CALIB 7.1 and the data set of Marine 13 (Reimer et al., 2013) with a local reservoir age (delta $R$ ) of $72.0 \pm 40.0$ by linear interpolation (Fig. 2a and Table 1 ).

The gravity core $\mathrm{T} 1\left(30^{\circ} 42^{\prime} 00^{\prime \prime} \mathrm{N}, 122^{\circ} 54^{\prime} 00^{\prime \prime} \mathrm{E}\right)$ (Fig. 1) was recovered at the subaqueous Yangtze River delta. The lithology is

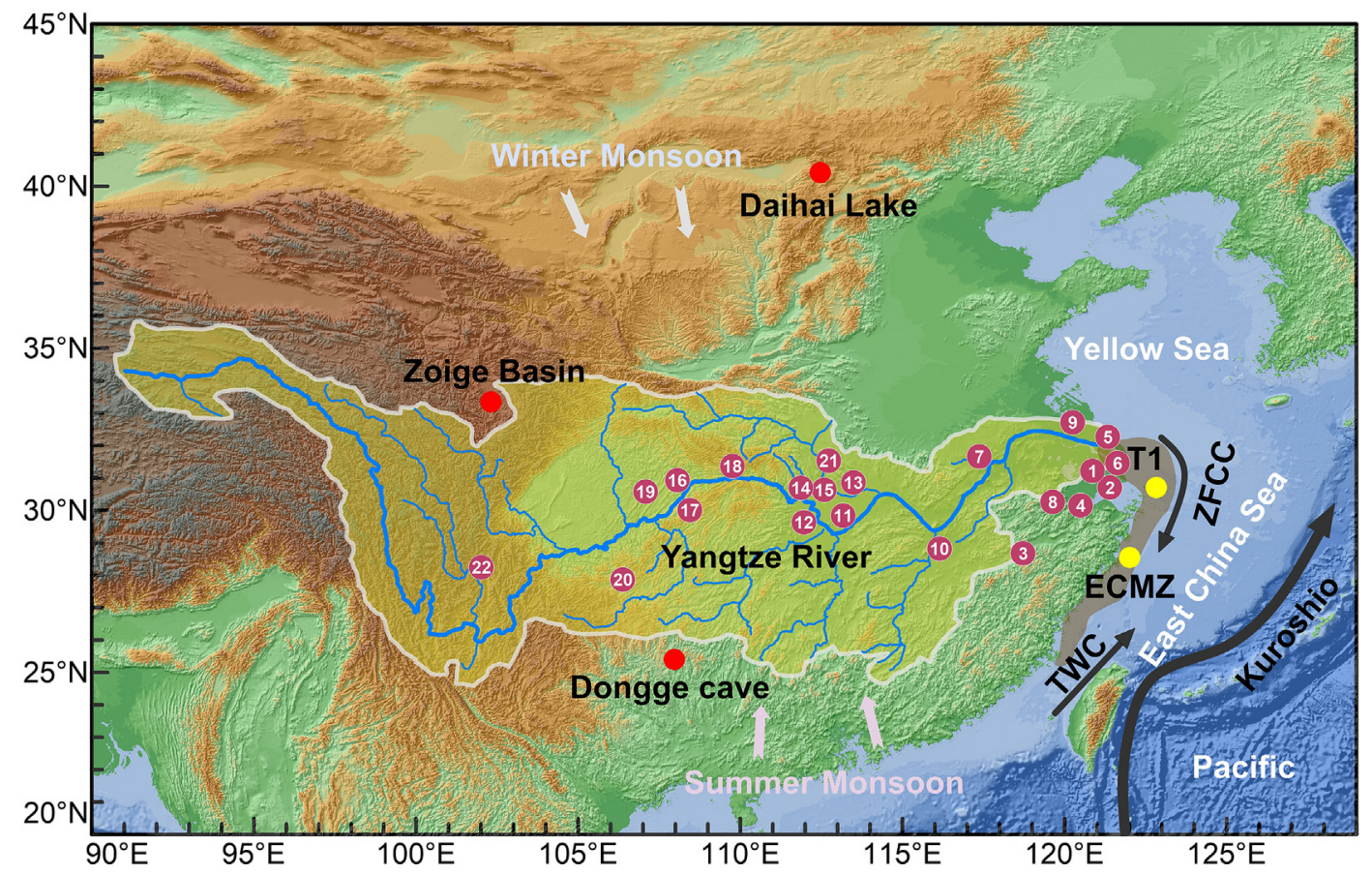

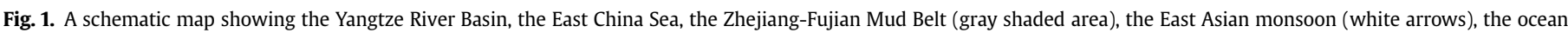

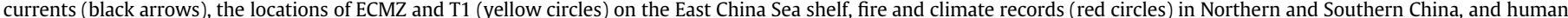

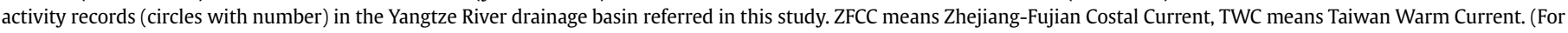
interpretation of the references to color in this figure legend, the reader is referred to the Web version of this article.) 


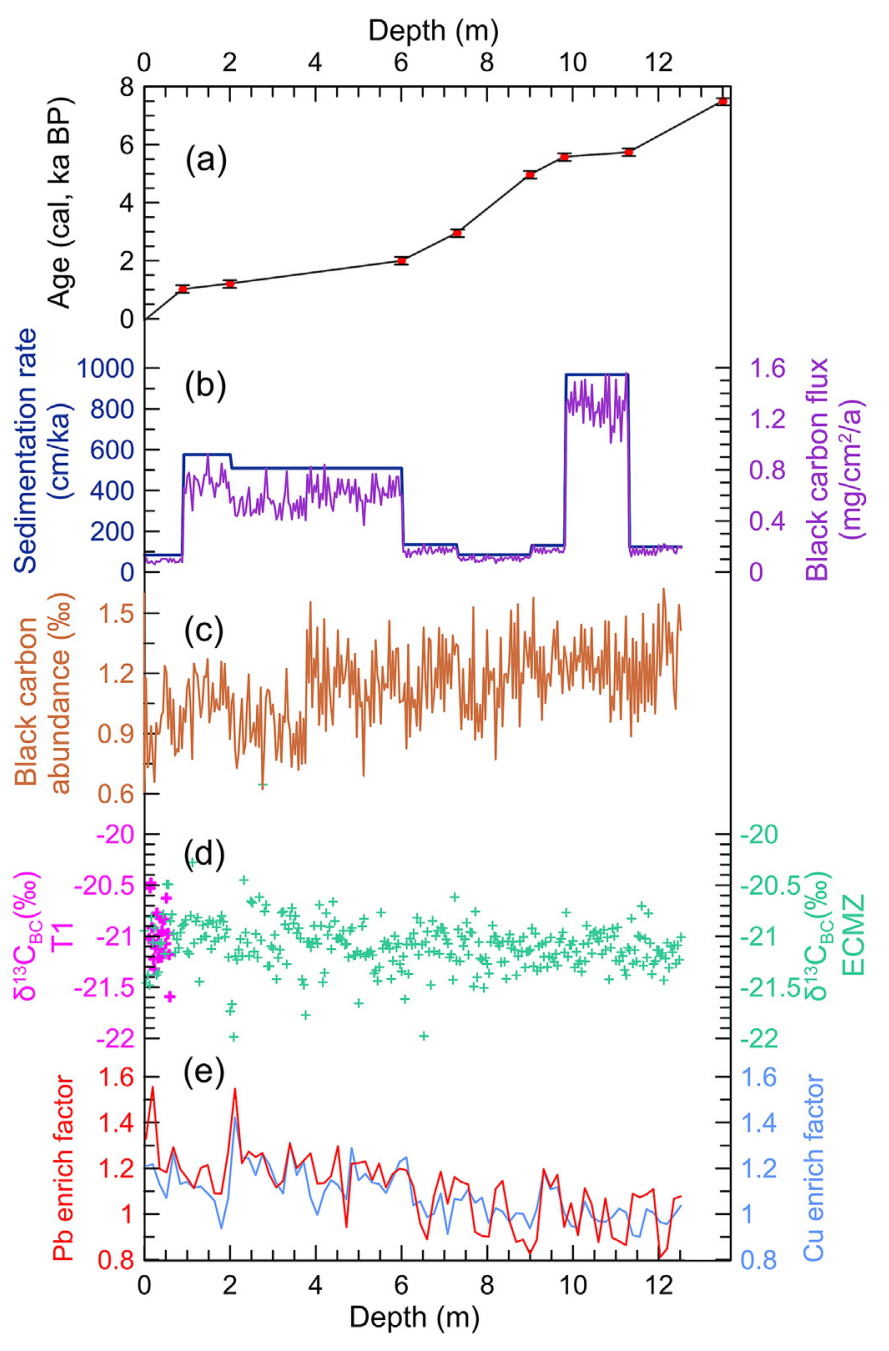

Fig. 2. Results of (a) age model, (b) sedimentation rate and black carbon flux, (c) black carbon abundance from ECMZ, (d) $\delta^{13} \mathrm{C}$ of black carbon from ECMZ (green symbols) and T1 (pink symbols), (e) the enrichment (enrich) factor of $\mathrm{Pb}$ (red line) and $\mathrm{Cu}$ (blue line) from ECMZ. (For interpretation of the references to color in this figure legend, the reader is referred to the Web version of this article.)

dark gray clayey silt and silty clay. Based on the average sedimentation rate $(500 \mathrm{~cm} / \mathrm{ka}$ ) in this area (Xu et al., 2012), the upper $0.5 \mathrm{~m}$ of core T1 was formed over the last $\sim 100$ years. The sediment samples of core T1 were used to constrain the nature of black carbon originating from the Yangtze River.

\subsection{Black carbon analysis}

Both abundance and carbon isotope compositions $\left(\delta^{13} \mathrm{C}\right)$ of black carbon were analyzed for core ECMZ at an interval of $4 \mathrm{~cm}$ and for
T1 at an interval of $2 \mathrm{~cm}$, respectively. Chemical oxidation method developed by Lim and Cachier (1996) is used for black carbon extraction. 1-3 g dried bulk sediments were firstly treated with a solution of $\mathrm{HCl}(3 \mathrm{~mol} / \mathrm{L}$ ) for $24 \mathrm{~h}$ to remove carbonates. Then, the silicate minerals and refractory oxides were sequentially dissolved by $\mathrm{HF}(10 \mathrm{~mol} / \mathrm{L})+\mathrm{HCl}(1 \mathrm{~mol} / \mathrm{L})$ and $\mathrm{HCl}(10 \mathrm{~mol} / \mathrm{L})$ for $24 \mathrm{~h}$. Finally, the acid-treated samples were oxidized by a mixture of $\mathrm{K}_{2} \mathrm{Cr}_{2} \mathrm{O}_{7}$ ( $0.1 \mathrm{~mol} / \mathrm{L})$ and $\mathrm{H}_{2} \mathrm{SO}_{4}(2 \mathrm{~mol} / \mathrm{L})$ at $55^{\circ} \mathrm{C}$ for $60 \mathrm{~h}$ to remove organic matter and kerogen. Repeated process of centrifuge and rising (3-6 times) was carefully performed after each step. The remaining refractory carbon left in the residue was operationally defined as black carbon (Shen et al., 2018). The black carbon abundance and $\delta^{13} \mathrm{C}$ of black carbon $\left(\delta^{13} \mathrm{C}_{\mathrm{BC}}\right)$ were measured using a continuousflow isotope ratio mass spectrometer (CF-IRMS) at the Yantai Institute of Coastal Zone Research, Chinese Academy of Science. The CF-IRMS system consists of an EA (Flash 2000 series) coupled to a Finnigan MAT 253 mass spectrometer. The black carbon abundance is expressed as $\mathrm{mg} / \mathrm{g}$ dry sediment $(\% 0)$. And the $\delta^{13} \mathrm{C}_{\mathrm{BC}}$ is expressed using the conventional delta $(\delta)$ notation in per mil (\%o) deviation from the standard Vienna Pee Dee Belemnite (VPDB). Replicate analysis showed that the relative error was within 5\% for black carbon abundance. Reproducibility of the standard sample (Certificate no.162517) was better than $\pm 0.15 \%$ for $\delta^{13} \mathrm{C}$.

Morphology and chemical composition of black carbon particles were also investigated by scanning electron microscopy-energy dispersive spectroscopy (SEM-EDS) (Shen et al., 2018). Briefly, the residues after chemical extraction as described above were put on a slide, which were then mounted onto the conductive tape holder. The sample was then gold-coated before being analyzed by SEMEDS (Hitachi S-4800) (15 kV) at the Qingdao Institute of Marine Geology.

\subsection{Bulk mineralogy analysis}

15 bulk samples approximately evenly spaced in core ECMZ were chosen for mineral studies to discuss the potential impact of mineral on the distribution and preservation of black carbon. About $5 \mathrm{~g}$ dried bulk sediments were firstly dried and powdered homogenously, and then the bulk powders were packed gently into round samples holders to retain random particle orientation. The analysis was performed by X-ray diffraction (XRD) using a D8 ADVANCE diffractometer with CuK $\alpha$ (alpha) radiation $(40 \mathrm{kV}$, $40 \mathrm{~mA}$ ) over a scanning range of $3^{\circ}-60^{\circ} 2 \theta$ in the laboratory of the Institute of Oceanology, Chinese Academy of Sciences. The digital data was processed using Topas 2P software to establish the basal reflection for the main minerals. The empirical factors were as follows: quartz, intensity of the $4.24 \AA$ peak multiplied by 2.86 ; Kfeldspar and plagioclase, intensity of the $3.21 \AA$ and $3.16 \AA$ peaks multiplied peak multiplied by 2 ; calcite and dolomite, intensity of the $3.03 \AA$ and $2.89 \AA$ A peaks multiplied peak multiplied by 1.92 ; total clay mineral composition, the intensity of the common $4.4 \AA$ reflection, multiplied by 20 (Boski et al., 1998; Cook et al., 1975).

Table 1

$\mathrm{AMS}^{14} \mathrm{C}$ data and calibrated ages of core ECMZ.

\begin{tabular}{|c|c|c|c|c|c|}
\hline BETA No. & Depth $(\mathrm{cm})$ & Material & $\mathrm{AMS}^{14} \mathrm{C}$ age (a BP) & Calibrated age (a BP) & $2 \sigma(\mathrm{a} B P)$ \\
\hline 516932 & $88-92$ & Benthic foraminifera & $1540 \pm 30$ & 1020 & $914-1151$ \\
\hline $453406^{\mathrm{a}}$ & $200-202$ & Carbonate shells & $1720 \pm 30$ & 1211 & $1080-1300$ \\
\hline $453408^{a}$ & $600-602$ & Benthic foraminifera & $2440 \pm 30$ & 1997 & $1865-2132$ \\
\hline 516934 & $730-734$ & Benthic foraminifera & $3240 \pm 30$ & 2962 & $2820-3129$ \\
\hline $453410^{a}$ & $900-902$ & Benthic foraminifera & $4800 \pm 30$ & 4968 & $4831-5137$ \\
\hline 516936 & $980-982$ & Benthic foraminifera & $5290 \pm 30$ & 5583 & $5463-5693$ \\
\hline 516937 & $1130-1132$ & Benthic foraminifera & $5440 \pm 30$ & 5738 & $5614-5873$ \\
\hline $453412^{\mathrm{a}}$ & $1350-1352$ & Benthic foraminifera & $7090 \pm 30$ & 7510 & $7418-7595$ \\
\hline
\end{tabular}

Note: ${ }^{\mathrm{a}} \mathrm{AMS}{ }^{14} \mathrm{C}$ data is from Dong et al. (2018). 
Replicate analysis of the same sample produced results with a relative error margin of $\pm 5 \%$.

\subsection{Heavy metals analysis}

Heavy metals were also investigated for the top $13 \mathrm{~m}$ of core ECMZ at an interval of $16 \mathrm{~cm}$ following the method developed by Loring and Rantala (1992). $40 \mathrm{mg}$ dried bulk sediments were firstly treated with an acid mixture $\left(5: 4: 1 \mathrm{HNO}_{3}+\mathrm{HCl}+\mathrm{HF}\right)$ for $12 \mathrm{~h}$. The residues were then subsequently treated with $\mathrm{HClO}_{4}$ for $3 \mathrm{~h}$ and $\mathrm{HNO}_{3}$ for $12 \mathrm{~h}$, respectively. The remaining solution was finally adjusted to $40 \mathrm{~g}$ with deionized water. Heavy metals $(\mathrm{Cu}, \mathrm{Pb})$ were analyzed by inductively coupled plasma-atomic emission spectrometry (ICP-AES) and ICP mass spectrometry (ICP-MS) in the laboratory of the Institute of Oceanology, Chinese Academy of Sciences. The analytical precision is generally better than $3 \%$. In order to discriminate between natural and anthropogenic sources of heavy metals, the enrichment factor is calculated by the following equation:

enrichment factor $=\left(\mathrm{X}_{\text {sample }} / \mathrm{Al}_{\text {sample }}\right) /\left(\mathrm{X}_{\text {baseline }} / \mathrm{Al}_{\text {baseline }}\right)$

where $\mathrm{X}_{\text {sample }}\left(\mathrm{X}_{\text {baseline }}\right)$ and $\mathrm{Al}_{\text {sample }}\left(\mathrm{Al}_{\text {baseline }}\right)$ are heavy metal concentrations and aluminum contents of samples (background references), respectively (Wan et al., 2015). Average elements concentration of 23 samples older than $5.0 \mathrm{ka} \mathrm{BP}$ is regarded as not influenced by anthropogenic process and is thus used as the reference baselines.

\section{Results}

As shown in Fig. 2c and Table S1, black carbon abundance ranges between $0.6 \%$ and $1.6 \%$ in core ECMZ, with generally high value $(\sim 1.2 \%$ ) but slightly decreasing trend upwards between $13 \mathrm{~m}$ and $4 \mathrm{~m}$, and relative low value $(\sim 0.9 \%$ ) for the top $4 \mathrm{~m}$, respectively. The $\delta^{13} C_{B C}$ varies from $-22 \%$ to $-20 \%$ for core $E C M Z$, and from $-21.7 \%$ to $-20.5 \%$ for core T1 (Fig. 2 d, Table S1 and Table S2). The value of $\delta^{13} C_{B C}$ for both cores shows similar average value
$(-21.1 \%$ o $)$ and no clear downcore trend.

The morphology and grain size of the black carbon are shown by typical SEM photographs (Fig. 3). The morphology of black carbon at core ECMZ mainly occurs as subround-subangular thick platetype and irregular polyhedra. The black carbon grain size of core ECMZ is generally smaller than $50 \mu \mathrm{m}$ and some particles are in clay size $(<4 \mu \mathrm{m})$. EDS results indicate black carbon particles are mainly composed of elemental carbon (Fig. 3).

Minerals identified from core ECMZ consist mainly of clay (65-78\%), quartz (9-16\%), feldspar (8-16\%), and calcite (2-7\%) (Table S3), and there is a lack of long-term trend among major minerals content during the last $7.0 \mathrm{ka}$.

The enrichment factor of both $\mathrm{Pb}$ and $\mathrm{Cu}$ displays a similar trend. Generally, relative low value $(0.8-1.1)$ occurs below $\sim 6 \mathrm{~m}$, and an increasing trend (from 1.1 to 1.6 ) is observed above $\sim 6 \mathrm{~m}$ (Fig. $2 \mathrm{e}$ and Table S4).

\section{Discussion}

\subsection{Provenance of black carbon}

Black carbon represents a continuum from char, charcoal to graphite carbon, which is produced by incomplete combustion of fossil fuels and vegetation (Goldberg, 1985). Because of its inertness and widespread distribution in sediments, black carbon has been applied as a useful tracer for fire history (Bird and Cali, 1998).

However, black carbon in sediments can originate over a range of spatial scales (Clark et al., 1997). Therefore, constraints on the provenance of black carbon are essential for understanding the fire signal recorded in core ECMZ. Once black carbon was produced by fire events, some of the material remained proximal to the site where it was formed, while the rest was transported via rivers and winds to marine depocenters, due to its low density (Forbes et al., 2006). As for black carbon in coastal oceans, it is dominated by fluvial supply (Forbes et al., 2006). This is exactly the case for the East China Sea adjacent to the Yangtze River. It is estimated that the annual flux of black carbon particles in the Yangtze River is up to $2.0 \times 10^{11} \mathrm{~g} \mathrm{C}$, accounting for $\sim 2 \%$ of the global black carbon buried
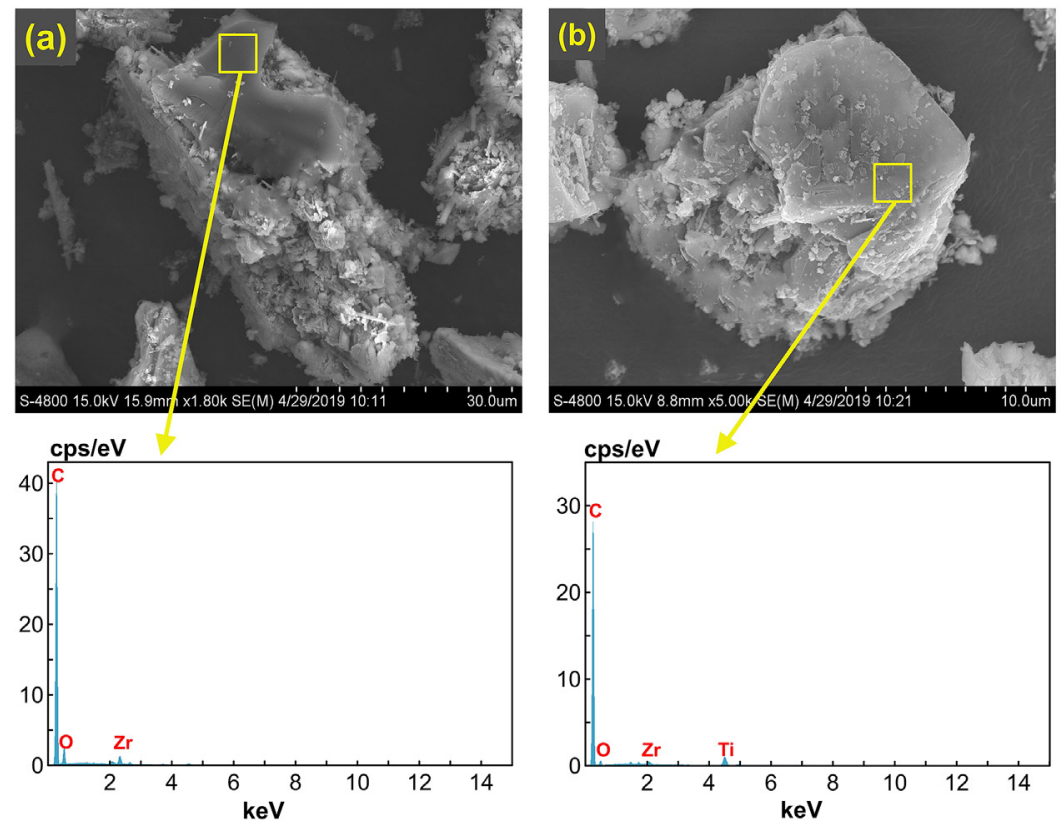
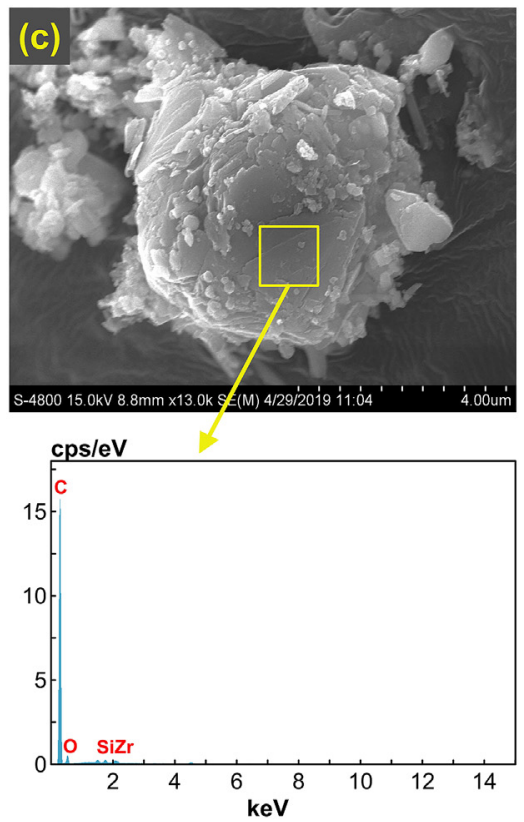

Fig. 3. SEM photographs and EDS results of black carbon from core ECMZ. 


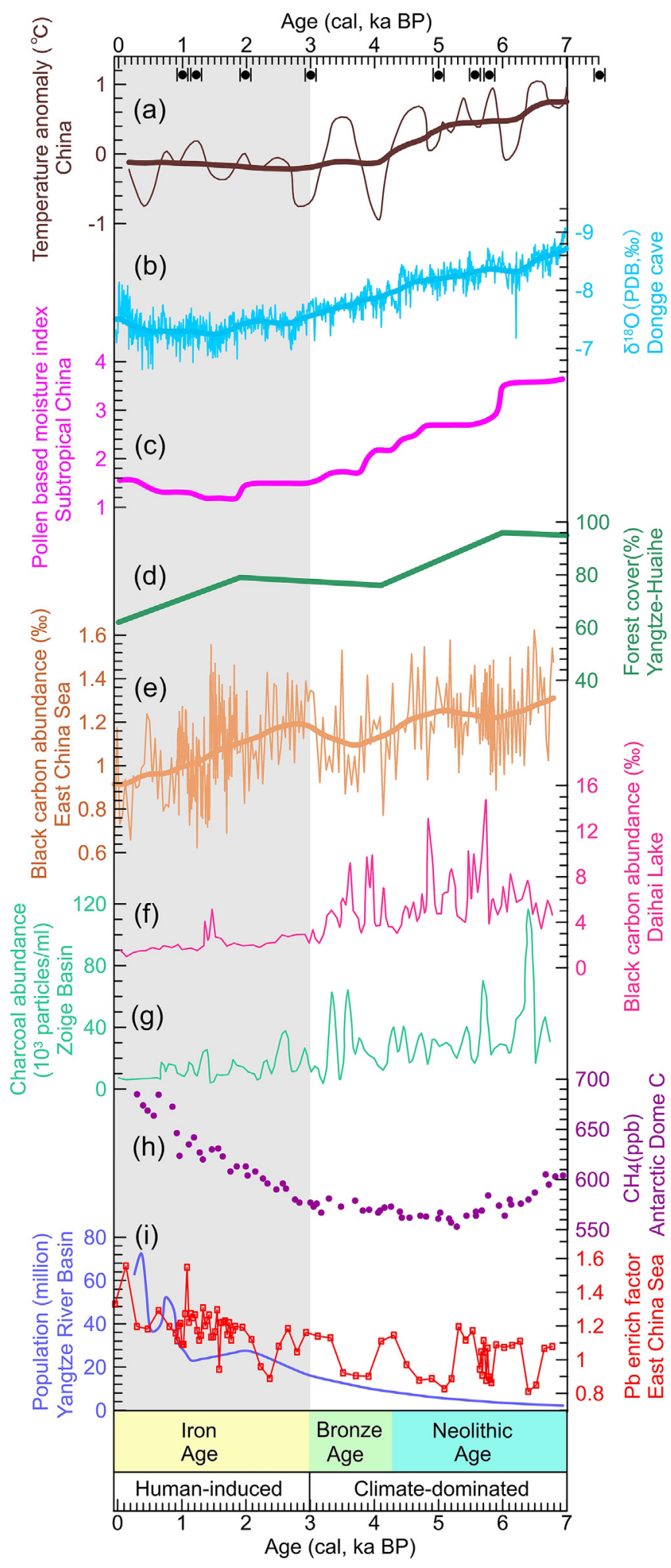

Fig. 4. Comparison of millennial-timescale variation of black carbon and heavy metal records from ECMZ with other continental and ice records since $7.0 \mathrm{ka}$ BP. (a) Temperature anomaly in China (Hou and Fang, 2012). (b) Asian Summer monsoon proxy of stalagmite $\delta^{18} \mathrm{O}$ at Dongge Cave (Wang et al., 2005). (c) Pollen-based moisture index in subtropical China (Zhao et al., 2009). (d) Forest cover in Yangtze-Huaihe (Ren, 2007). (e) Regional fire activities recorded by black carbon from core ECMZ (this study). (f) Fire activities recorded by black carbon at Daihai Lake (Wang et al., 2013). (g) Fire activities recorded by charcoal at Zoige Basin (Zhao et al., 2017). (h) Atmospheric methane concentrations from the ice core of Antarctic Dome C (Augustin et al., 2004). (i) $\mathrm{Pb}$ enrichment (enrich) factor from core ECMZ (this study) and population amount annually in the ocean (Xu et al., 2016). A rough calculation of black carbon fluxes in ECMZ by multiplying the black carbon concentrations by the sedimentation rate suggests the black carbon flux reaches $0.1-1.5 \mathrm{mg} \mathrm{C} / \mathrm{cm}^{2} / \mathrm{a}$ (Fig. $2 \mathrm{~b}$ ), which is much higher than the flux of eolian-derived black carbon to Pacific coastal waters ( $0.005 \mathrm{mg} \mathrm{C} / \mathrm{cm}^{2} / \mathrm{a}$ ) (Clark et al., 1997), and also indicates that the eolian input is negligible. The subround-subangle black carbon particles from ECMZ (Fig. 3) also imply they were mostly transported from the drainage basin through rivers (Li et al., 2009a). Combining evidence from clay mineral, heavy metal, geochemical and grain size data sets also supports that the Yangtze River is the primary source for fine-grained terrigenous materials in the ZFMB where core ECMZ was located (Liu et al., 2006). We thus expect that the Yangtze River should play an important role in delivering black carbon to the coastal region. This is confirmed by a decreasing trend of black carbon abundance from the Yangtze River estuary southwards to the continental shelf of the East China Sea in surface sediments (Wang and $\mathrm{Li}, 2007$ ). Moreover, the $\delta^{13} \mathrm{C}_{\mathrm{BC}}$ can be used to trace the source of black carbon because the $\delta^{13} C_{B C}$ value is systematically slightly lower $(\sim 0.3 \%$ ) than that of its precursory vegetation because of fractionation during burning (Bird and Gröcke, 1997). Almost all of the $\delta^{13} C_{B C}$ of core ECMZ since $7.0 \mathrm{ka}$ BP lies within the range of black carbon $(-21.7 \%$ o to $-20.5 \%$ o measured at sediment core T1 in the Yangtze River delta during the last 100 years (Fig. 2d), confirming that the Yangtze River is the major sediment source of black carbon in the ECMZ. Moreover, the generally constant value of $\delta^{13} C_{B C}$ (Fig. 2d) suggests that the source of black carbon to the ECMZ was stable and supplied from the Yangtze River since 7.0 ka BP.

\subsection{Interpretation of black carbon}

The fire signal preserved in black carbon in marine sediments could be possibly concealed by changes in sediment flux or lithology in response to complex transport and sedimentation processes (Conedera et al., 2009). It should be noted that sedimentation rates show large fluctuations, ranging from $\sim 90$ to $\sim 950 \mathrm{~cm} / \mathrm{ka}$ (Fig. 2b), which might be linked to changes in climate or human activity (Xu et al., 2012). Such changes in sedimentation rate could affect black carbon flux because they are both related to the riverine sediment input (Quintana Krupinski et al., 2013). High positive correlation of black carbon flux with sedimentation rate $\left(\mathrm{R}^{2}=0.94, \mathrm{P}<0.01\right)$ (Fig. S1c) implies that the black carbon flux is significantly mediated by variations in sedimentation rate rather than the production rate of black carbon associated with biomass burning. In contrast, the lack of correlation between black carbon abundance and sedimentation rates $\left(\mathrm{R}^{2}=0.00017, \mathrm{P}<0.01\right.$ ) (Fig. S1b) suggests that fluctuations in black carbon abundance are not related to sedimentation rate. The homogeneous lithology found in the upper $13 \mathrm{~m}$ of core ECMZ since $7.0 \mathrm{ka} \mathrm{BP}$, as well as the absence of correlation between black carbon abundance and terrigenous grain size $\left(R^{2}=0.016, P<0.01\right)$ (Dong et al., 2018) (Fig. S1a), suggests that black carbon was unlikely to have been influenced by hydrodynamic sorting. Moreover, the lack of correlations between black carbon abundance and the bulk mineralogy (clay minerals, quartz + feldspar and calcite) (Fig. S1d, e and f) strongly suggests that black carbon abundance was not affected by dilution effects of the other sediment fractions.

Therefore, the abundance of black carbon in the study core is hardly affected by hydraulic sorting or mixing processes, but

around the Yangtze River Basin extracted from HYDE 3.1 (Goldewijk et al., 2010). Thick lines show running average of temperature anomaly, stalagmite $\delta^{18} \mathrm{O}$ and black carbon abundance, which reveal their long-term trend. Gray bands indicate periods of increasing human impact on fire. 
instead can be used to represent variations in black carbon production, which is a function of fire activity (Quintana Krupinski et al., 2013). Combining with the provenance constraints discussed above, we emphasize that the black carbon abundance in core ECMZ sediment could reflect the average intensity of regional fire activity throughout the Yangtze River Basin, rather than individual fire events in any particular local area. Thus, higher black carbon abundance in this study implies stronger fire activity, or more biomass burnt in the Yangtze River Basin during the time of sedimentation. The general decline trend of regional fire activity recorded in ECMZ (Fig. 4e) is consistent with charcoal or black carbon records from the eastern Tibetan Plateau (Zhao et al., 2017) (Fig. 4g) and north-central China (Wang et al., 2013) (Fig. 4f), suggesting that gradual weakening of fire activity since $7.0 \mathrm{ka} \mathrm{BP}$ is a common phenomenon across broad regions of China under the influence of the East Asia monsoon.

\subsection{Climatic controls on fire activity at 7.0-3.0 ka BP}

A comparison of black carbon abundance and climatic proxies (Fig. 4) suggests that the long-term decrease in regional fire activity between 7.0 and $3.0 \mathrm{ka}$ BP generally followed the trend of reducing temperature in mainland China (Hou and Fang, 2012) (Fig. 4a) and precipitation inferred from Dongge Cave speleothem isotopic records (Wang et al., 2005) (Fig. 4b), as well as pollen-based moisture indices in the Yangtze River Basin (Zhao et al., 2009) (Fig. 4c). Correlation analysis also reveals positive correlation between fire activity and precipitation and temperature (Fig. 5a and b). On a global scale, it has been suggested that intensity of fire activity increases monotonically with temperature rise, while the impact of moisture on fire intensity is complex and depends on the initial vegetation conditions (Daniau, 2012). Moisture not only increases vegetative cover (fuel load), but at the same time also reduces fuel flammability, which have opposing influences on fire activity (Daniau, 2012). However, our result implies that both increased temperature and moisture might have strengthened regional fire activity in the Yangtze River Basin at 7.0-3.0 ka BP, indicating that the influence of fuel availability on biomass burning overwhelmed fuel flammability under warm and humid conditions. This conclusion is also supported by the generally parallel varied pattern of regional fire activity and forest cover in the Yangtze River Basin (Ren, 2007) (Fig. 4d and e).

In addition, there were also several centennial-timescale fire abnormalities superimposed on the long-term (millennial-timescale) trend of fire activity during 7.0-3.0 ka BP (Fig. 6), possibly reflecting the rapid response of fire to abrupt climate changes. Most
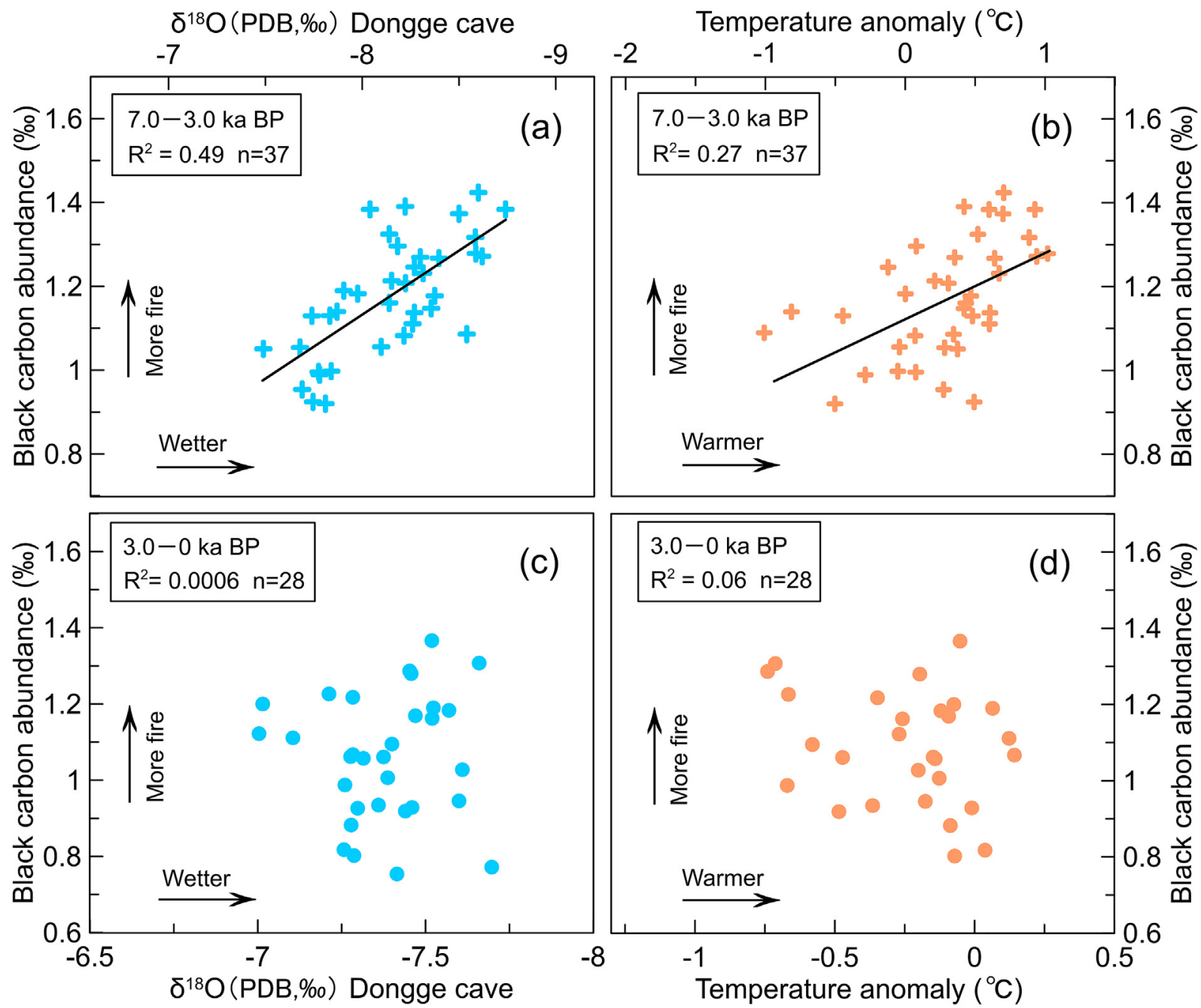

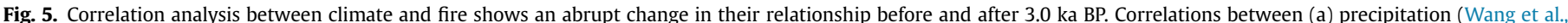

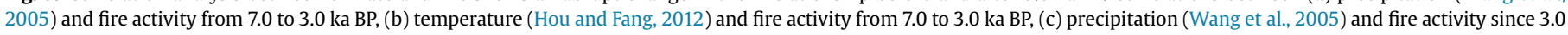
ka BP, (d) temperature (Hou and Fang, 2012) and fire activity since 3.0 ka BP. All data is transformed into equally spaced time intervals (100 a) by linear interpolation. 


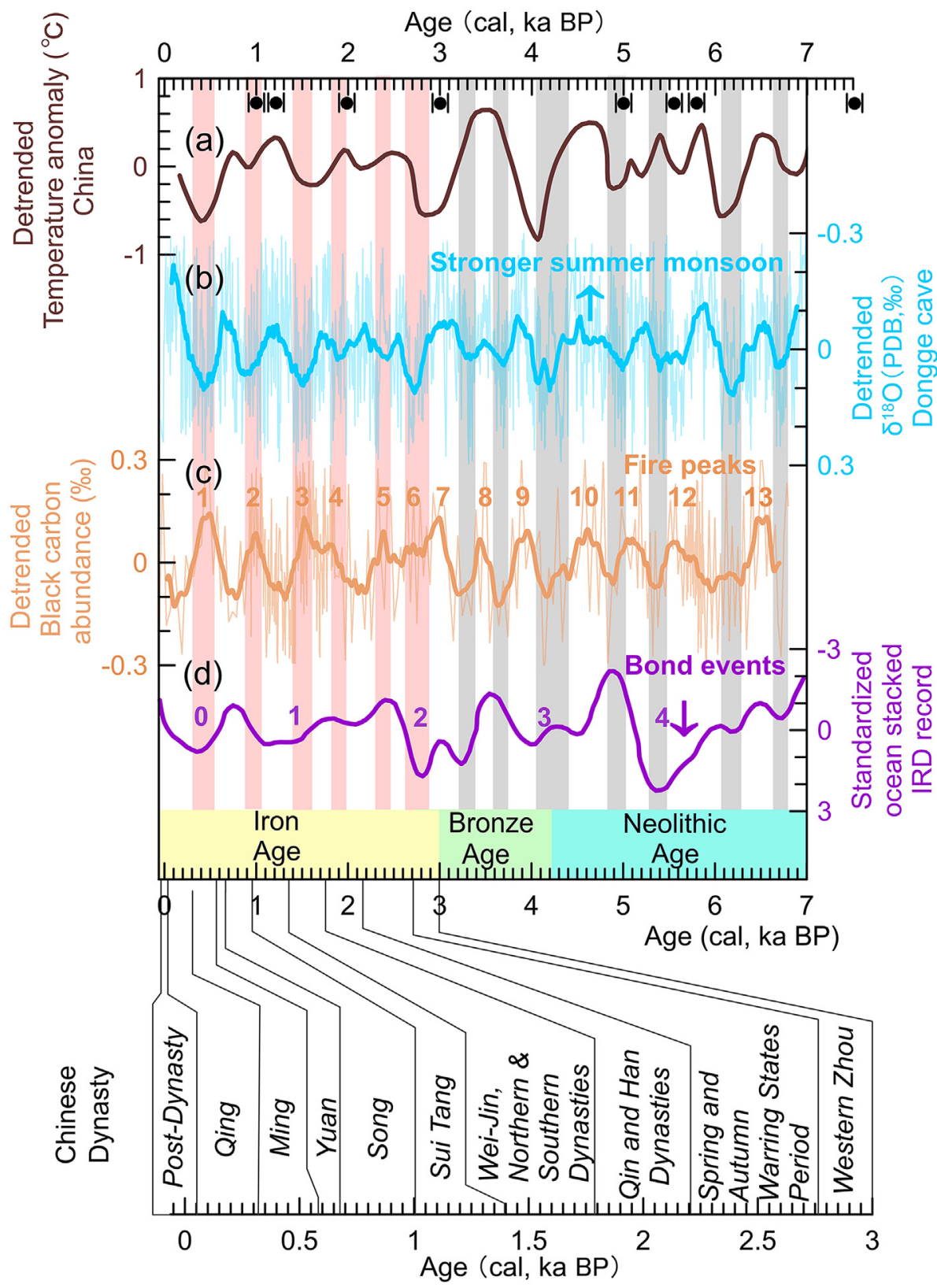

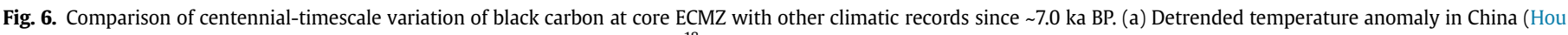

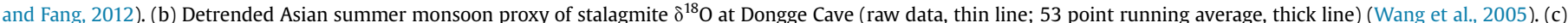

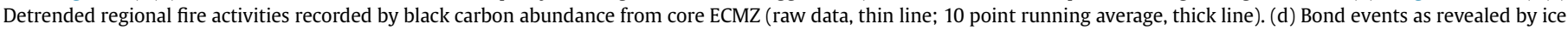

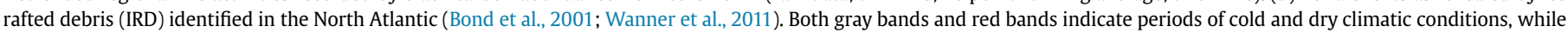

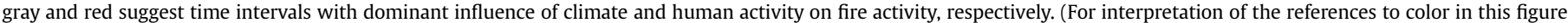
legend, the reader is referred to the Web version of this article.)

of these intervals characterized by intensified fire activity (fire peaks 7-13) (Fig. 6c) correspond well with periods of higher temperature (Hou and Fang, 2012) (Fig. 6a) and stronger East Asian summer monsoon precipitation (Wang et al., 2005) (Fig. 6b). In contrast, low fire activity usually occurred during periods of colder and drier climate conditions, including Bond events 3 and 4 identified in the North Atlantic (Bond et al., 2001) (Fig. 6d). Such close relationships between fire and climate on multiple time scales suggest a dominant control by climate and climate-induced changes in vegetation on the regional fire activity in the Yangtze River Basin at 7.0-3.0 ka BP.

\subsection{Enhanced human impact on fire since $~ 3.0 \mathrm{ka} \mathrm{BP}$}

There has been a clear divergence between fire and climate change since $\sim 3.0$ ka BP (Fig. 4; Fig. $5 \mathrm{c}$ and d). Climatic proxies suggest both long-term temperature and precipitation have remained relatively constant from $\sim 3.0$ to $1.0 \mathrm{ka} B P$ and then slightly increased since about $1.0 \mathrm{ka} \mathrm{BP}$. At the same time regional fire activity showed a rapid decline since $\sim 3.0 \mathrm{ka} B P$. This argues against a direct relationship between fire, temperature and precipitation in the Yangtze River Basin during this period. We suggest that human activity might have played a more important role in regulating biomass burning than climate change. It has been 


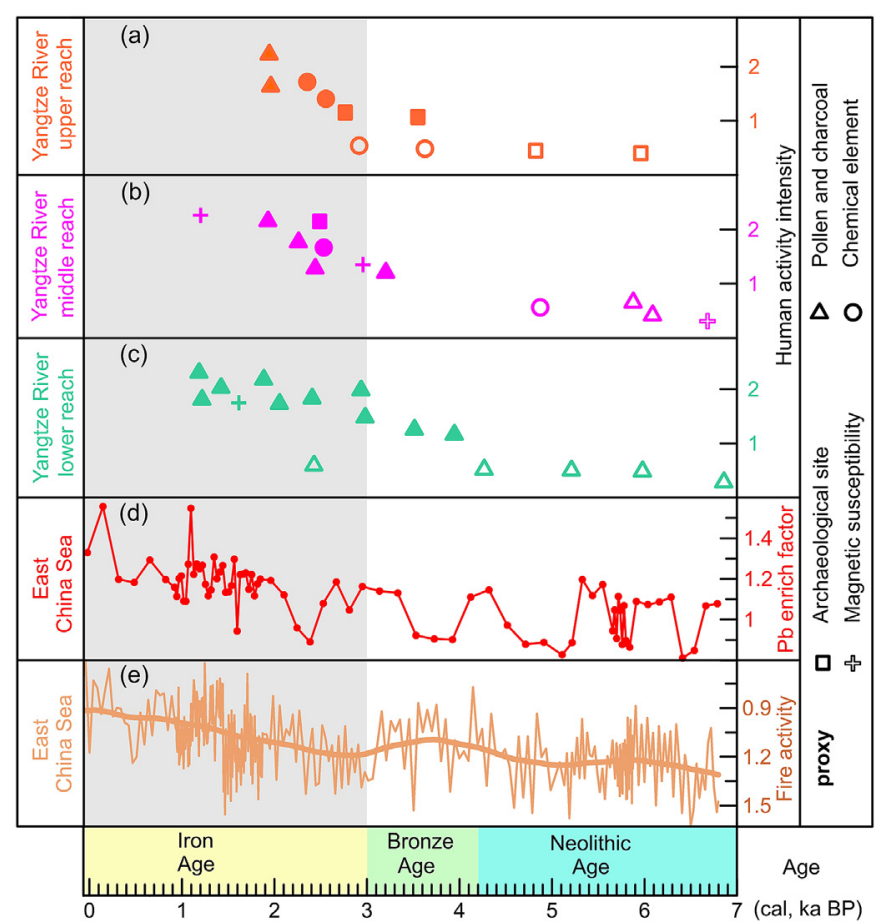

Fig. 7. Comparison of human activity intensity revealed by various proxy records from source to sink including (a) the upper reaches, (b) middle reaches, (c) lower reaches of the Yangtze River Basin, and (d) Pb enrichment (enrich) factor and (e) black carbon records from the East China Sea since 7.0 ka BP. More details and references are listed in Table 2. For (a), (b) and (c), symbols with no color filling represent periods when gathering and hunting dominated the economy and living style (value of human activity intensity $<1$ ), symbols with color filling represent periods when farming dominated the economy and profound human impacts on environment (value of human activity intensity $>1$ ). (For interpretation of the references to color in this figure legend, the reader is referred to the Web version of this article.)

reported that humans learnt to ignite fire as early as the middle Pleistocene (Glikson, 2013). Since then, fire has been increasingly used for heating, cooking, hunting and above all, for agriculture, thus altering fire regimes in the geologic past (Wang et al., 2013; Zong et al., 2007). Previous studies suggested that fire had been used to clear forests and maintain grassland vegetation for rice cultivation and settlement since $\sim 7.7 \mathrm{ka} B P$ in limited regions in the lower Yangtze River (Zong et al., 2007). It should be noted that most people still engaged in hunting and gathering wild food during that period, especially in mountainous areas, which had little impacts on regional environment before about $3 \mathrm{ka}$ BP (Fig. 7 and Table 2) (Hosner et al., 2016; Innes et al., 2009; Li et al., 2009b, 2012; Ma et al., 2016; Xie et al., 2008; Yi et al., 2003). Only since the onset of the Iron Age, did rice agriculture gradually dominate the economy with the development and widespread use of iron tools, as revealed by various proxies, including pollen and charcoal, soil organic carbon, magnetic susceptibility, heavy metals and archaeological relics, from different sites around the Yangtze River Basin since about $3.0 \mathrm{ka} \mathrm{BP}$ (Figs. 1 and 7 and Table 2) (Atahan et al., 2008; Chen et al., 2009; Gao et al., 2005; Gu et al., 2013; Huang et al., 2004; Innes et al., 2019; Jiang and Piperno, 1999; Li et al., 2010, 2013; Ma et al., 2016; Ren, 2000; Wang et al., 2011; Zhu et al., 2002, 2007, 2010). Our study confirms that the dominant anthropogenic forcing of regional fire activity in the Yangtze River Basin did not occur until $\sim 3.0$ ka BP. This is consistent with the significant increase in atmospheric methane concentration since that time (Fig. 4h), which was thought to be the result of widespread rice production in the Yangtze River Basin (Ruddiman et al., 2008). The enrichment factor of $\mathrm{Pb}$ and $\mathrm{Cu}$ in core ECMZ also shows an abrupt increase from $\sim 3.0 \mathrm{ka} \mathrm{BP}$ (Fig. 4i), suggesting more anthropogenic input of heavy metals probably caused by intensified metal mining and metal tool manufacture in the Yangtze River Basin. With the development of agriculture, populations in the drainage area tended to grow at an exponential rate (Fig. 4i), as revealed from the History Database of the Global Environment (HYDE 3.1) (Goldewijk et al., 2010).

Intuitively, an enhancement of regional fire activity would be expected due to the abrupt increase in population and extension of agriculture (Wang et al., 2013). However, increased human activity (i.e., deforestation, cultivation and mining) can also reduce vegetation cover and limit fuel load (Quintana Krupinski et al., 2013). Therefore, the generally decreasing trend in black carbon abundance most likely suggests a long-term reduction in biomass burning in the Yangtze River Basin since $3.0 \mathrm{ka}$ BP (Fig. 4e). Similar decreasing trends were also observed in a synthesis of global biomass burning since $2.0 \mathrm{ka} B \mathrm{~B}$, despite the increase in population (Marlon et al., 2013). This apparent mismatch between low fire activity and high human intervention could be explained by the

Table 2

Human activity revealed by proxy records from different sitesa around the Yangtze River Basin since 7.0 ka BP.

\begin{tabular}{|c|c|c|c|c|}
\hline Site no. & Proxy & Age (cal, ka BP) weak human activity & Age (cal, ka BP) strong human activity & Reference \\
\hline 1 & Pollen & 2.4 & 1.5 & Innes et al. (2019) \\
\hline 2 & Pollen and charcoal & 7.0 & $4.0 ; 2.4$ & Atahan et al. (2008) \\
\hline 3 & Pollen and charcoal & & $3.0 ; 2.1$ & Ma et al. (2016) \\
\hline 4 & Pollen and charcoal & 6.0 & & Innes et al. (2009) \\
\hline 5 & Pollen & 4.5 & 1.3 & Yi et al. (2003) \\
\hline 6 & Magnetic susceptibility & & 1.7 & Wang et al. (2011) \\
\hline 7 & Pollen & & 3.7 & Chen et al. (2009) \\
\hline $8 ; 21$ & Pollen & 5.3 & $3.0 ; 2.4 ; 1.0$ & Li et al. (2010) \\
\hline $9 ; 22$ & Pollen & & 2.0 & Ren (2000) \\
\hline 10 & Pollen & & $2.6 ; 1.95$ & Jiang and Piperno (1999) \\
\hline 11 & Heavy metals & 5.0 & 2.7 & Gu et al. (2013) \\
\hline 12 & Magnetic susceptibility & 6.8 & $3.0 ; 1.2$ & Li et al. (2012) \\
\hline 13 & Archaeological site & & 2.7 & Zhu et al. (2007) \\
\hline 14 & Pollen & 6.2 & 3.4 & Xie et al. (2008) \\
\hline 15 & Pollen and charcoal & 6.0 & 2.4 & Li et al., 2009b \\
\hline 16 & Soil organic carbon & 3.0 & 2.4 & Gao et al. (2005) \\
\hline 17 & $\mathrm{Hg}$ & 3.8 & 2.7 & Huang et al. (2004) \\
\hline 18 & Pollen and charcoal & & 2.0 & Zhu et al. (2002) \\
\hline 19 & Archaeological site & 6.0 & 3.0 & Zhu et al. (2010) \\
\hline 20 & Archaeological site & 5.0 & 3.5 & Li et al. (2013) \\
\hline
\end{tabular}

Note: ${ }^{a}$ the location of proxy record is shown in Fig. 1. 
low biomass availability indicated by the marked decrease in forest cover in the Yangtze River Basin (Ren, 2007) (Fig. 4d). With constant expansion of agriculture, primeval forest was gradually transformed into permanent cropland (Wang et al., 2010). Fire was thus limited due to the lack of fuel and the associated landscape fragmentation, with increasing human impact on the environment (i.e., deforestation, cultivation).

In addition to the long-term changes on millennial-timescale discussed above, the short-term (centennial-timescale) relationship between fire and climate also seems to have been altered by human activity since $\sim 3.0 \mathrm{ka}$ BP. Episodes of high fire activity were relatively common at $0.4-0.6 \mathrm{ka} \mathrm{BP}, 0.9-1.1 \mathrm{ka} \mathrm{BP}, 1.4-1.6 \mathrm{ka} \mathrm{BP}$, 1.8-1.9 ka BP, 2.4-2.5 ka BP and 2.6-2.7 ka BP (fire peaks 1-6) (Fig. 6c), during which both temperature and precipitation usually exhibit local minima (Fig. 6a and b). This is again in contrast with the climatic control on fire between 7.0 and $3.0 \mathrm{ka} \mathrm{BP}$ (as discussed above), further supporting our idea that humans started to dominate fire activity on regional scales since $3.0 \mathrm{ka}$ BP. It is not a coincidence that the response of fire to climate over the short term is opposite to that over the longer term (i.e., more fire during cold and dry climate). Most of the periods of fire peak were, within dating error, almost contemporaneous with periods characterized by increased human activity associated with population migration or technological advance. For example, the fire peaks 6 and 5 at 2.7-2.4 ka BP coincided with the rise and development of Iron Age cultures during the late Zhou Dynasty, which marked an important stage for the expansion of agriculture (Calloe et al., 2005). Fire peak 4 at 1.9-1.8 ka BP, fire peak 3 at 1.6-1.4 ka BP and fire peak 2 at $1.1-0.9$ ka BP coincided with large-scale population migrations to Southern China (the Yangtze River Basin) from Northern China (the Yellow River Basin) during the late Han Dynasty, Wei Jin Southern and Northern Dynasties and Tang-Song period, respectively (Zhang, 2000). Several lines of paleoclimatic and archaeological evidence suggest that prolonged periods of drought and cold climate would result in crop failure, resource depletion, warfare and population migration (Zhang et al., 2008). This is especially the case for Northern China, where society is more sensitive to severe climatic conditions because of the relative high latitudes (Pei et al., 2016). Southern China, in contrast, is more benign for human habitation and agriculture during drought and cold climate events, a difference that drove population migration towards the south (Zhang et al., 2007). Large-scale migrations not only greatly contributed to regional population growth, but also introduced advanced agricultural technology. In particular, fire peak 1 at $0.5-0.3 \mathrm{ka}$ BP correlates well with the timing of the introduction of corn and potatoes that were able to grow in mountainous areas during the Ming Dynasty, which allowed more regions to be reclaimed for agricultural use (Gu et al., 2013). These findings indicate that a significant increase in human activity could promote more biomass burning during specific periods over short terms, possibly as a result of forest clearing by fire to generate more farmland (Jiang et al., 2006). Biomass burning shows no sign of enhancement in the other periods, possibly because farmland already reclaimed was sufficient to feed the existing populace since no additional significant increase in population occurred during those periods.

\section{Conclusions and implications}

In this study, we reconstruct a high-resolution regional fire history in the Yangtze River Basin, and reveal clear changes from climate-dominated fire regimes to human-dominated fire regimes at $\sim 3.0 \mathrm{ka}$ BP on multi time scales, which is important to evaluate the role humans played in modifying the Earth system by the use of fire. The age $3.0 \mathrm{ka}$ BP, therefore, probably provides insights into in the division of the Anthropocene at least in the Yangtze River Basin, since fire is a potential index for the stratigraphic definition of the Anthropocene (Glikson, 2013). Other studies from the middle and upper reaches of the Yellow River Basin (Huang et al., 2006; Wang et al., 2013), the south-western Amazonia (Urrego et al., 2013) and the Mediterranean Basin (Vannière et al., 2011) also reveal that the human influence on fire activity became increasingly important since around 4.0-3.0 ka BP. More regional fire records are encouraged to reconstruct, especially in the estuary of large rivers such as the Yellow, Amazon, the Nile, the Mississippi Rivers and so on, where contains integrated burning imprint of the whole drainage basin (Bird and Cali, 1998). This will largely help us to assess the time and magnitude of human effects on fire from a global perspective.

We also find a distinct response of regional fire to increasing human interference on different time scales. The long-term regional fire activities since $\sim 3.0 \mathrm{ka} B \mathrm{BP}$ were suppressed because of the general decrease in forest cover in the Yangtze River region due to increasing human activities. While in the short term (centennial time-scales), marked increase in human activities associated with population migration or technology advance during some colder and drier periods could promote more biomass burning. Furthermore, fire is an important tool that humans use to modify the global carbon cycle (Bond-Lamberty et al., 2007). Although it seems that the general decline in global fire activity over the last several millennia contradicts the idea that increasing human-induced fire could increase greenhouse gas concentrations (Marlon et al., 2013), we note that as well as promoting emissions of greenhouse gas directly by setting fire, humans could also alter the global carbon cycle indirectly by gradually transforming original forest into permanent farmland with the use of fire, which is not the case for natural fires. Thus, the indirect impact of regulating landscape by human-induced fire should not be neglected when assessing the contribution of fire to human influence on the global carbon cycle.

\section{Acknowledgments}

We acknowledge the scientific party and technicians of drilling vessel Kan 407 for recovering the samples. We also thank the editor Antje Voelker and two anonymous reviewers for their constructive comments. This work was supported by the National Natural Science Foundation of China (41622603, 41576034, 41430965, U1606401), National Program on Global Change and Air-Sea Interaction (GASI-GEOGE-02, GASI-GEOGE-03), Open Fund of the Key Laboratory of Marine Geology and Environment, CAS (MGE2018KG03), Taishan and Aoshan Talents program (2017ASTCP-ES01), and Innovation project of Qingdao National Laboratory for Marine Science and Technology (2016ASKJ13 and MGQNLM-TD201805).

\section{Appendix A. Supplementary data}

Supplementary data to this article can be found online at https://doi.org/10.1016/j.quascirev.2020.106165.

\section{References}

Archibald, S., Roy, D.P., van Wilgen, B.W., Scholes, R.J., 2009. What limits fire? An examination of drivers of burnt area in Southern Africa. Glob. Chang. Biol. 15, $613-630$.

Atahan, P., Itzstein-Davey, F., Taylor, D., Dodson, J., Qin, J., Zheng, H., Brooks, A., 2008 Holocene-aged sedimentary records of environmental changes and early agriculture in the lower Yangtze, China. Quat. Sci. Rev. 27, 556-570.

Augustin, L., Barbante, C., Barnes, P.R.F., Barnola, J.M., Bigler, M., Castellano, E. Cattani, O., Chappellaz, J., Dahljensen, D., Delmonte, B., 2004. Eight glacial cycles from an Antarctic ice core. Nature 429, 623-628.

Bird, M.I., Cali, J.A., 1998. A million-year record of fire in sub-Saharan Africa. Nature 
394, 767-769

Bird, M.I., Gröcke, D.R., 1997. Determination of the abundance and carbon isotope composition of elemental carbon in sediments. Geochem. Cosmochim. Acta 61, 3413-3423.

Bond-Lamberty, B., Peckham, S.D., Ahl, D.E., Gower, S.T., 2007. Fire as the dominant driver of central Canadian boreal forest carbon balance. Nature 450, 89-92.

Bond, G., Kromer, B., Beer, J., Muscheler, R., Evans, M.N., Showers, W., Hoffmann, S., Lotti-Bond, R., Hajdas, I., Bonani, G., 2001. Persistent solar influence on north atlantic climate during the Holocene. Science 294, 2130-2136.

Boski, T., Pessoa, J., Pedro, P., Thorez, J., Dias, J.M.A., Hall, I.R., 1998. Factors governing abundance of hydrolyzable amino acids in the sediments from the N.W. European Continental Margin (47-50 N). Prog. Oceanogr. 42, 145-164.

Calloe, K., Nielsen, M.S., Grunnet, M., Schmitt, N., Jorgensen, N.K., 2005. The Formation of Chinese Fivilization. An Archaeological Perspective. Yale University Press.

Chen, W., Wang, W.M., Dai, X.R., 2009. Holocene vegetation history with implications of human impact in the Lake Chaohu area, Anhui Province, East China. Veg. Hist. Archaeobotany 18, 137-146.

Clark, J.S., Cachier, H., Goldammer, J.G., Stocks, B.J., 1997. Sediment Records of Biomass Burning and Global Change, vol. 51. Nato Asi.

Conedera, M., Tinner, W., Neff, C., Meurer, M., Dickens, A.F., Krebs, P., 2009. Reconstructing past fire regimes: methods, applications, and relevance to fire management and conservation. Quat. Sci. Rev. 28, 555-576.

Cook, H.E., Johnson, P.D., Matti, J.C., Zemmels, I., 1975. IV. Methods of sample preparation, and X-ray diffraction data analysis, X-ray mineralogy laboratory. In: Deep Sea Drilling Project, vol. 25. University of California, Riverside. Initial Rep. Deep Sea Drill. Proj.

Daniau, A.L., 2012. Predictability of biomass burning in response to climate changes. Glob. Biogeochem. Cycles 26, GB4007.

Dong, J., Li, A.C., Liu, X.T., Wan, S.M., Feng, X.G., Lu, J., Pei, W.Q., Wang, H.L., 2018. Sea-level oscillations in the East China Sea and their implications for global seawater redistribution during 14.0-10.0 kyr BP. Palaeogeogr. Palaeoclimatol. Palaeoecol. 511, 298-308.

Forbes, M.S., Raison, R.J., Skjemstad, J.O., 2006. Formation, transformation and transport of black carbon (charcoal) in terrestrial and aquatic ecosystems. Sci. Total Environ. 370, 190-206.

Gao, Z.H., Zhu, C., Sun, Z.B., 2005. Distribution of soil organic carbon in archaeological strata of Zhongba site in Three Gorges reservoir and its relation to human activities. Acta Pedol. Sin. 42, 518-522.

Gf, B.W.M., Woodward, F.I., 2010. The importance of low atmospheric $\mathrm{CO}_{2}$ and fire in promoting the spread of grasslands and savannas. Glob. Chang. Biol. 9, 973-982.

Glikson, A., 2013. Fire and human evolution: the deep-time blueprints of the Anthropocene. Anthropocene 3, 89-92.

Goldberg, E.D., 1985. Black Carbon in the Environment. John Wiley\& Sons, New York.

Goldewijk, K.K., Beusen, A., Janssen, P., 2010. Long-term dynamic modeling of global population and built-up area in a spatially explicit way: HYDE 3.1. Holocene 20, 565-573.

Gu, Y.S., Li, K.J., Qin, Y.M., Qi, S.H., Ge, J.W., Li, W., 2013. Impact of human activity on the evolution of the ecological environment of Jianghan Lake Group in the historical period, central China. Earth Sci. 38, 133-144.

Han, Y.M., Marlon, J.R., Cao, J.J., Jin, Z.D., An, Z.S., 2012. Holocene linkages between char, soot, biomass burning and climate from Lake Daihai, China. Glob. Biogeochem. Cycles 26, GB4017.

Hosner, D., Wagner, M., Tarasov, P.E., Chen, X., Leipe, C., 2016. Spatiotemporal distribution patterns of archaeological sites in China during the Neolithic and Bronze Age: an overview. Holocene 26, 1576-1593.

Hou, G.L., Fang, X.Q., 2012. Characteristics analysis and synthetical reconstruction of regional temperature series of the Holocene in China. J. Palaeogeogr. 14, 243-252.

Huang, R., Zhu, C., Sun, Z.B., Zheng, C.G., Ma, C.M., 2004. Distribution characteristics of $\mathrm{Hg}$ concentrations in strata at Zhongba site profile and analysis of influential factors. Geol. Geochem. 32, 44-48.

Huang, C.C., Pang, J.L., Chen, S.E., Su, H.X., Han, J., Cao, Y.F., Zhao, W.Y., Tan, Z.H., 2006. Charcoal records of fire history in the Holocene loess-soil sequences over the southern Loess Plateau of China. Palaeogeogr. Palaeoclimatol. Palaeoecol. 239, 28-44.

Innes, J.B., Zong, Y.Q., Chen, Z.Y., Chen, C., Wang, Z.H., Wang, H., 2009. Environmental history, palaeoecology and human activity at the early Neolithic forager/ cultivator site at Kuahuqiao, Hangzhou, eastern China. Quat. Sci. Rev. 28 2277-2294

Innes, J.B., Zong, Y., Xiong, H., Wang, Z., Chen, Z., 2019. Pollen and non-pollen palynomorph analyses of Upper Holocene sediments from Dianshan, Yangtze coastal lowlands, China: hydrology, vegetation history and human activity. Palaeogeogr. Palaeoclimatol. Palaeoecol. 523, 30-47.

Jiang, Q., Piperno, D.R., 1999. Environmental and archaeological implications of a late quaternary palynological sequence, Poyang lake, southern China. Quat. Res. $52,250-258$

Jiang, P.H., Xie, S.Y., Xiong, P.S., 2006. Recalling human activities affecting China's geographical environmental changes. J. Chongqing Technol. Bus. Univ. 4, 414-417.

Justino, F., Peltier, W.R., Barbosa, H.A., 2010. Atmospheric susceptibility to wildfire occurrence during the Last Glacial Maximum and mid-Holocene. Palaeogeogr. Palaeoclimatol. Palaeoecol. 295, 76-88.
Li, F., Wu, L., Zhu, C., Sun, W., Wang, X.C., Meng, H.P., Liu, H., Qi, S.Z., Gong, Q.L., Zhu, G.Y., 2012. A high-resolution study of moisture evolution in the Jianghan plain since 12.76 cal. ka B.P. Sci. Geogr. Sin. 32, 878-884.

Li, Z., Yoshiki, S., Dang, P.X., Eiji, M., Quang Lan, V., 2009. Warfare rather than agriculture as a critical influence on fires in the late Holocene, inferred from northern Vietnam. Proc. Natl. Acad. Sci. U. S. A 106, 11490-11495.

Li, K.F., Zhu, C., Wang, X.H., Cao, B., Zhao, X.F., 2013. The archaeological sites distribution and its relationship with physical environment from around $260 \mathrm{ka} B$ to 221 BC in Guizhou Province. Acta Geograph. Sin. 68, 58-68.

Li, Y.G., Hou, S.F., Mo, D.W., 2009. Records for pollen and charcoal from Qujialing archaeological site of Hubei and ancient civilization development. J. Palaeogeogr. 11, 702-710.

Li, Y.Y., Wu, J., Hou, S.F., Shi, C.X., Duowen, M., Liu, B., Zhou, L.P., 2010. Palaeoecological records of environmental change and cultural development from the Liangzhu and Qujialing archaeological sites in the middle and lower reaches of the Yangtze River. Quat. Int. 227, 29-37.

Lim, B., Cachier, H., 1996. Determination of black carbon by chemical oxidation and thermal treatment in recent marine and lake sediments and CretaceousTertiary clays. Default J. 131, 143-154.

Liu, J.P., Li, A.C., Xu, K.H., Velozzi, D.M., Yang Z.S., Milliman, J.D., DeMaster, D.J., 2006. Sedimentary features of the Yangtze River-derived along-shelf clinoform deposit in the east China sea. Cont. Shelf Res. 26, 2141-2156.

Liu, J.P., Xu, K.H., Li, A.C., Milliman, J.D., Velozzi, D.M., Xiao, S.B., Yang, Z.S., 2007. Flux and fate of Yangtze River sediment delivered to the east China sea. Geomorphology 85, 208-224.

Loring, D., Rantala, R., 1992. Manual for the geochemical analyses of marine sediments and suspended particulate matter. Earth Sci. Rev. 32, 235-283.

Ma, T., Tarasov, P.E., Zheng, Z., Han, A., Huang, K., 2016. Pollen- and charcoal-based evidence for climatic and human impact on vegetation in the northern edge of Wuyi Mountains, China, during the last 8200 years. Holocene 26, 1616-1626.

Marlon, J.R., Bartlein, P.J., Walsh, M.K., Harrison, S.P., Brown, K.J., Edwards, M.E. Higuera, P.E., Power, M.J., Anderson, R.S., Briles, C., Brunelle, A., Carcaillet, C., Daniels, M., Hu, F.S., Lavoie, M., Long, C., Minckley, T., Richard, P.J., Scott, A.C. Shafer, D.S., Tinner, W., Umbanhowar Jr., C.E., Whitlock, C., 2009. Wildfire responses to abrupt climate change in North America. Proc. Natl. Acad. Sci. U. S. A 106, 2519-2524.

Marlon, J.R., Bartlein, P.J., Daniau, A.-L., Harrison, S.P., Maezumi, S.Y., Power, M.J., Tinner, W., Vanniére, B., 2013. Global biomass burning: a synthesis and review of Holocene paleofire records and their controls. Quat. Sci. Rev. 65, 5-25.

Pei, Q., Zhang, D.D., Lee, H.F., 2016. Contextualizing human migration in different agro-ecological zones in ancient China. Quat. Int. 426, 65-74.

Quintana Krupinski, N.B., Marlon, J.R., Nishri, A., Street, J.H., Paytan, A., 2013. Climatic and human controls on the late Holocene fire history of northern Israel Quat. Res. 80, 396-405.

Reimer, P.J., Bard, E., Bayliss, A., Beck, J.W., Blackwell, P.G., Ramsey, C.B., Buck, C.E. Cheng, H., Edwards, R.L., Friedrich, M., Grootes, P.M., Guilderson, T.P., Haflidason, H., Hajdas, I., Hatté, C., Heaton, T.J., Hoffmann, D.L., Hogg, A.G. Hughen, K.A., Kaiser, K.F., Kromer, B., Manning, S.W., Niu, M., Reimer, R.W. Richards, D.A., Scott, E.M., Southon, J.R., Staff, R.A., Turney, C.S.M., van der Plicht, J., 2013. IntCal13 and Marine13 radiocarbon age calibration curves 0-50,000 Years cal BP. Radiocarbon 55, 1869-1887.

Ren, G.Y., 2000. Decline of the mid- to late Holocene forests in China: climatic change or human impact? J. Quat. Sci. 15, 273-281.

Ren, G.Y., 2007. Changes in forest cover in China during the Holocene. Veg. Hist. Archaeobotany 16, 119-126.

Ruddiman, W.F., Guo, Z., Zhou, X., Wu, H., Yu, Y., 2008. Early rice farming and anomalous methane trends. Quat. Sci. Rev. 27, 1291-1295.

Shen, X., Wan, S.M., Colin, C., Tada, R., Shi, X., Pei, W., Tan, Y., Jiang, X., Li, A., 2018. Increased seasonality and aridity drove the C4 plant expansion in Central Asia since the Miocene-Pliocene boundary. Earth Planet. Sci. Lett. 502, 74-83.

Urrego, D.H., Bush, M.B., Silman, M.R., Niccum, B.A., Paulina, D.L.R., Mcmichael, C.H., et al., 2013. Holocene fires, forest stability and human occupation in southwestern Amazonia. J. Biogeogr. 40, 521-533.

Vannière, B., Power, M.J., Roberts, N., Tinner, W., Carrión, J., Magny, M., Bartlein, P., Colombaroli, D., Daniau, A.L., Finsinger, W., Gil-Romera, G., Kaltenrieder, P., Pini, R., Sadori, L., Turner, R., Valsecchi, V., Vescovi, E., 2011. Circum-Mediterranean fire activity and climate changes during the mid-Holocene environmental transition (8500-2500 cal. BP). Holocene 21, 53-73.

Wan, S.M., Toucanne, S., Clift, P.D., Zhao, D.B., Bayon, G., Yu, Z.J., Cai, G.O., Yin, X.B. Révillon, S., Wang, D.W., Li, A.C., Li, T.G., 2015. Human impact overwhelms longterm climate control of weathering and erosion in southwest China. Geology $43,439-442$.

Wang, W.M., Shu, J.W., Chen, W., Ding, J.L., 2010. Holocene environmental changes and human impact in the Yangtze River Delta area, east China. Quat. Sci. 30, $233-244$.

Wang, X., Li, A., 2007. Preservation of black carbon in the shelf sediments of the East China Sea. Chin. Sci. Bull. 52, 3155-3161.

Wang, X., Xiao, J., Cui, L., Ding, Z., 2013. Holocene changes in fire frequency in the Daihai Lake region (north-central China): indications and implications for an important role of human activity. Quat. Sci. Rev. 59, 18-29.

Wang, Y., Cheng, H., Edwards, R.L., He, Y., Kong, X., An, Z., Wu, J., Kelly, M.J., Dykoski, C.A., Li, X., 2005. The Holocene Asian monsoon: links to solar changes and North Atlantic climate. Science 308, 854-857.

Wang, Z.H., Li, M.T., Zhang, R.H., Zhuang, C.C., Liu, Y., Saito, Y., Xie, J.L., Zhao, B.C., 2011. Impacts of human activity on the late-Holocene development of the 
subaqueous Yangtze delta, China, as shown by magnetic properties and sediment accumulation rates. Holocene 21, 393-407.

Wanner, H., Solomina, O., Grosjean, M., Ritz, S.P., Jetel, M., 2011. Structure and origin of Holocene cold events. Quat. Sci. Rev. 30, 3109-3123.

Wu, L., Li, F., Zhu, C., Li, L., Li, B., 2012. Holocene environmental change and archaeology, Yangtze River valley, China: review and prospects. Geosci. Front. 3 , $875-892$.

Xie, Y.Y., Li, C.A., Wang, Q.L., Yin, H.F., 2008. Palynological records of early human activities in Holocene at Jiangling area, Hubei province. Sci. Geogr. Sin. 28, $276-281$.

Xu, C., Xue, Y., Qi, Y., Wang, X., 2016. Quantities and fluxes of dissolved and particulate black carbon in the Changjiang and Huanghe Rivers, China. Estuar. Coasts 39, 1617-1625.

Xu, K., Li, A., Liu, J.P., Milliman, J.D., Yang, Z., Liu, C.-S., Kao, S.-J., Wan, S., Xu, F., 2012 Provenance, structure, and formation of the mud wedge along inner continental shelf of the East China Sea: a synthesis of the Yangtze dispersal system. Mar. Geol. 291-294, 176-191.

Xue, J.B., Zhong, W., Li, Q., Cheng, R., You, A., Wei, Z.Q., Shang, S.T., 2018. Holocene fire history in eastern monsoonal region of China and its controls. Palaeogeogr. Palaeoclimatol. Palaeoecol. 496, 136-145.

Yi, S., Saito, Y., Zhao, Q.H., Wang, P.X., 2003. Vegetation and climate changes in the Changjiang (Yangtze River) Delta, China, during the past 13,000 years inferred from pollen records. Quat. Sci. Rev. 22, 1501-1519.

Zhang, D.D., Brecke, P., Lee, H.F., He, Y.Q., Zhang, J., 2007. Global climate change, war and population decline in recent human history. Proc. Natl. Acad. Sci. U. S. A 104, 19214-19219.
Zhang, D.X., 2000. The effect of population activity on the changes in vegetation of Yangtze River Valley since the ancient period of Spring and Autumn-Warring States (770-221B.C.). J. Plant Resour. Environ. 9, 47-53.

Zhang, P., Cheng, H., Edwards, R.L., Chen, F., Wang, Y., Yang, X., Liu, J., Tan, M., Wang, X., Liu, J., 2008. A test of climate, sun, and culture relationships from an 1810-year Chinese cave record. Science 322, 940-942.

Zhao, W., Zhao, Y., Qin, F., 2017. Holocene fire, vegetation, and climate dynamics inferred from charcoal and pollen record in the eastern Tibetan Plateau. J. Asian Earth Sci. 147, 9-16.

Zhao, Y., Yu, Z., Chen, F., Zhang, J., Yang, B., 2009. Vegetation response to Holocene climate change in monsoon-influenced region of China. Earth Sci. Rev. 97, 242-256.

Zheng, Y., Jiang, L., 2009. Remains of ancient rice unearthed from the Shangshan site and their significance. Chin. Archaeol. 9, 159-163.

Zhu, C., Zhang, Q., Zhang, Z.H., Yu, S.Y., 2002. Rise and fall of human civilization and eco-environment evolution at Three Gorges of the Yangtze River. Quat. Sci. 22, $442-450$.

Zhu, C., Zhong, Y.S., Zheng, C.G., Ma, C.M., Li, L., 2007. Relationship of archaeological sites distribution and environment from the paleolithic age to the warring states time in Hubei province. Acta Geograph. Sin. 62, 227-242.

Zhu, C., Ma, C.M., Li, L., Sun, Z.B., Zheng, C.G., Bai, J.J., Zhu, G.Y., 2010. The progress in the study of environmental archaeology during the Holocene in Three Gorges reservoir area of the Yangtze River. Earth Sci. Front. 17, 222-232.

Zong, Y., Chen, Z., Innes, J.B., Chen, C., Wang, Z., Wang, H., 2007. Fire and flood management of coastal swamp enabled first rice paddy cultivation in east China. Nature 449, 459-462. 